\title{
Significance of Doppler Ultrasonography in Assessment of Thyroid Nodules
}

\section{Tiroid Nodüllerinin Değerlendirilmesinde Doppler Ultrasonografisinin Önemi}

\author{
(D) Mehmet Celal Kızılkayal, (D) Türkan İkizceli2 \\ IUniversity of Health Sciences Turkey, Kanuni Sultan Süleyman Training and Research Hospital, Clinic of General Surgery, İstanbul, Turkey \\ 2University of Health Sciences Turkey, Haseki Training and Research Hospital, Clinic of Radiology, İstanbul, Turkey
}

\begin{abstract}
Objective: We aimed to compare Doppler ultrasonography (USG) findings and histopathological results after the operation on benign and malign thyroid nodules.

Method: A total of 122 patients applied to general surgery clinic because of thyroid nodule which were planned to operate has been analyzed prospectively. These patients have been included in the study with preoperative Doppler USG and fine-needle aspiration biopsy (FNAB) findings.

Results: Ninety five patients were female, and 27 were male. The mean age was 47.1 years. The mean size of nodules was $25.6 \mathrm{~mm}$. Nodules had hypoechoic halo in 75 patients. Nodule vascularity increased in 81 patients. According to statistical analysis, there was a contrary relation between hypoechoic halo and malignancy $(p=-0.285)$. There was no relation between component and malignancy $(p=-0.032)$. We noted that malignancy was increasing with microcalcification. There was no relation between nodule margin and malignancy. It was observed that malignancy increased with vascularity.

Conclusion: With our study and information from the literature, in assessing thyroid nodules, examination of doppler USG is essential, and consideration with FNAB results makes preoperative diagnostic accuracy over $95 \%$.
\end{abstract}

Keywords: Thyroid, nodule, ultrasonography, Doppler, histopathology, surgery

\section{öz}

Amaç: Benign ve malign tiroid nodüllerinde Doppler ultrasonografi (USG) değerlendirmesi ile elde edilen verileri operasyon sonrası piyes histopatoloji sonuçları ile karșılaștırmayı amaçladık.

Yöntem: Bir yıl içerisinde genel cerrahi kliniğinde tiroid nodülü nedeni ile operasyon planlanan 122 hasta prospektif olarak incelenmiștir. Tiroid nodülü nedeni ile operasyon planlanan 122 hasta operasyondan önce tiroid Doppler USG ve ince iğne aspirasyon biyopsisi (iiAB) değerlendirmeleri tamamlanarak çalıșmaya dahil edilmiștir.

Bulgular: Çalıșmaya alınan hastaların 95'i kadın, 27'si erkekti. Hastaların yaș ortalaması 47,1'di. Nodül büyüklüğü ortalama 25,6 mm idi. Yetmiș beș hastada nodül hipoekoik haloya sahipti. Seksen bir hastada nodül vaskülaritesi artmıștı. Yapılan istatistiksel değerlendirme sonucu hipoekoik halo ile malignite arasında ters bir ilișki olduğu görüldü $(p=-0,285)$. Komponentle malignite arasında ilișki saptanmadı $(p=-0,032)$. Mikrokalsifikasyonun arttıkça malignitenin arttığı görüldü. Nodül marjini ile malignite arasında ilişki saptanmadı ( $>$ > 0,05). Vaskülarite arttıkça malignite arttığı gözlendi.

Sonuç: Yaptığımız çalıșma ve literatür bilgisi ıșığında tiroid nodüllerinin değerlendirmesinde Doppler USG incelemesinin asıında elzem olduğu ve bunun IïAB sonuçları ile birlikte değerlendirilmesi ile preoperatif tanı doğruluğunun \%95 ve üzerine çıkarılabileceği aşikardır.

Anahtar kelimeler: Tiroid, nodül, ultrasonografi, Doppler, histopatoloji, cerrahi

Cite as: Kızlkaya MC, Ikizceli T. Significance of Doppler Ultrasonography in Assessment of Thyroid Nodules. İKSSTD 2021;13(2):69-73 


\section{INTRODUCTION}

Thyroid nodules are common clinical findings and were detected in approximately $50 \%$ of autopsies ${ }^{(1)}$. In addition, thyroid nodules are seen in $4-7 \%$ of patients due to clinical studies ${ }^{(2,3)}$. Because of the increased use of neck ultrasonography on patients worldwide, the rate of thyroid nodule detection has exceeded $67 \%{ }^{(4)}$.

Approximately $67 \%$ of nodules are smaller than $15 \mathrm{~mm}$ (5). Therefore, it has been suggested that thyroid nodules smaller than $15 \mathrm{~mm}$ are not malignant and do not require further evaluation. However, it has been shown that small nodules can be malignant, and thus further research is needed in light of recent studies ${ }^{(5,6)}$.

USG and FNAB have generally accepted procedures in the evaluation of thyroid nodules ${ }^{(7,8)}$. However, there are not enough studies on the diagnostic value of FNAB for small nodules ${ }^{(5)}$. FNAB is a standard practice in detecting thyroid cancer. It has decreased the number of thyroid surgeries and increased the rate of cancer diagnoses during thyroid surgery $(9,10,11)$. However, sometimes FNAB may result in unnecessary surgery ${ }^{(12)}$. To prevent this, FNAB and Doppler USG findings can be evaluated together.

It is not possible to make a definitive diagnosis of malignancy by USG. Some features detected by USG suggest nodule malignancy. However, these features can be observed in both benign and malignant nodules ${ }^{(5,13,14)}$. Characteristics such as echogenicity, nodule size, presence and type of calcification, and presence or absence of a hypoechoic halo help us distinguish between malignant and benign nodules. Many guidelines recommend FNAB for solid nodules larger than $10 \mathrm{~mm}$ and mixed echoic nodules larger than $15 \mathrm{~mm}{ }^{(15,16)}$. Microcalcification is a specific marker of malignancy $(15,16,17)$, and intranodular and chaotic vascularity have been reported as ultrasound findings in suspected malignancies ${ }^{(16,17)}$.

This study compared the data obtained by Doppler USG evaluation of benign and malignant thyroid nodules with postoperative histopathologic results.

\section{METHOD}

\section{Patient Selection}

Patients scheduled for thyroid-nodule removal in the general surgery clinic within one year were prospectively examined. Approval was obtained from the ethics committee of Haseki Training and Research Hospital. In addition, informed consent was obtained from all patients. A total of 122 patients scheduled for thyroid-nodule removal were included in the study after completing preoperative thyroid Doppler USG and FNAB. Patients scheduled for surgery due to recurrent thyroid nodules and hyperthyroidism were excluded. Doppler USGs of all patients were performed with the Hitachi EUB-7500 Hi-Vision ultrasound device (Hitachi Global, Tokyo, Japan) by a radiology specialist.

\section{Image Analysis}

Thyroid nodules were first classified according to grayscale US findings. Intra-nodule vascularity was evaluated with power/color Doppler. The features of Doppler USG nodules were examined, and the nodules were divided into groups according to their margins, components, vascularity, and echogenicity and whether they contained microcalcifications or had hypoechoic haloes. The margins of the nodules were classified in the following ways: regular or irregular, with or without microcalcification, with or without hypoechoic haloes, solid or complex, whether vascularity was increased, and isoechoic or hypoechoic. The nodules were divided into 3 groups according to the RDUS findings: no obvious vascularity, presence of peripheral vascularity, and internal vascularity. According to Thyroid Imaging Reporting and Data System (TIRADS), the nodules were classified as 3-5.

By comparing the USG features of the groups of nodules with their FNAB (histopathology) results, we attempted to determine the relationship of the features revealed by USG to malignancy.

\section{Statistical Analysis}

For statistical analyses Kolmogorov-Smirnov and regression tests were carried out using the Statistical Package for Social Sciences 15.0 (SPSS, Inc., Chicago, IL, USA) for Windows.

\section{RESULTS}

In this study, 95 of the patients were female, and 27 were male. The mean age of the patients was $45.10 \pm 11.88$ years (age range: 20-72 years). According to the final histopathology results, 82 of the nodules were benign, and 40 were malignant. The average nodule size was $25.60 \pm$ $11.10 \mathrm{~mm}$, and the majority of the nodules had a regular margin and a solid component. In 75 patients, the nodule had a hypoechoic halo. Nodule vascularity was increased in 81 patients (Table 1 ).

Statistical analysis revealed an inverse relationship between hypoechoic haloes and malignancy $(p=-0.285)$. Malignancy decreases as hypoechoic halo increases. No relationship was found between components and malignancy ( $p=-0.032$ ). Malignancy was increased as microcalcification increase. No 
relationship between nodule margin and malignancy $(p>$ 0.05) was observed (Table 2).

Malignancy was observed to increase with increased vascularity (Figure la, lb). Therefore, RDUS findings, according to the type of vascularity, are given in Table 3.

As the TIRADS classification increased, malignancy rates increased when the nodules' features determined by Doppler USG were compared blindly with the FNAB results (Table 3 ).

\section{DISCUSSION}

In previous studies, 3.6-9.9\% of thyroid nodules were reported to be malignant ${ }^{(14,18-20)}$. In one study, sonographic data were not considered sufficient for distinguishing benign and malignant thyroid nodules, and FNAB was recommended in all cases ${ }^{(14)}$. In other studies, sonography could not distinguish benign and malignant nodules, and FNAB was

\begin{tabular}{|c|c|c|}
\hline $\begin{array}{l}\text { Age (year) mean } \pm \text { SD } \\
(\text { min-max) }\end{array}$ & & $47.10 \pm 11.88(20-72)$ \\
\hline \multirow{2}{*}{ Type n (\%) } & Female & $95(77.9)$ \\
\hline & Male & $27(22.1)$ \\
\hline \multicolumn{2}{|c|}{ Nodule size $(\mathrm{mm})$ mean $\pm \mathrm{SD}$} & $25.60 \pm 11.10$ \\
\hline \multirow{2}{*}{ Nodule margin } & Regular & $95(77.9)$ \\
\hline & Irregular & $27(22.1)$ \\
\hline \multirow{2}{*}{ Component } & Solid & $88(72.1)$ \\
\hline & Solid + cystic & $34(27.9)$ \\
\hline \multirow{2}{*}{ Echogenicity } & Isoechoic & $71(58.1)$ \\
\hline & Hypoechoic & $51(41.9)$ \\
\hline Hypoechoic halo & & $75(61.4)$ \\
\hline \multirow{2}{*}{ Calcification } & No & $54(44.2)$ \\
\hline & Yes & $68(55.8)$ \\
\hline Vascularity & & $81(67.4)$ \\
\hline \multicolumn{3}{|c|}{ SD: Standard deviation, min: Minimum, max: Maximum } \\
\hline
\end{tabular}

recommended in all cases ${ }^{(21,22)}$. However, in many studies, it has been stated that sonographic findings are useful for distinguishing benign and malignant nodules.

There is still uncertainty about which nodule properties are predictive of malignancy. One study suggested the presence of a single nodule, irregular borders, and microcalcification increased cancer risk 3.6, 5.4, and 39 times, respectively (23). Taneri et al. ${ }^{(24)}$ reported that the presence of multiple nodules is associated with malignancy, but Uğurlu et al. ${ }^{(23)}$ found that single or double nodules increased the risk of malignancy.

Cappeli et al. ${ }^{(18)}$ indicated a close relationship between solid and hypoechoic nodules with malignancy. However, in another study, hypoechogenicity was not associated with malignancy ${ }^{(25)}$. Undefined and irregular borders may increase the risk of solid and hypoechogenic nodule malignancy ${ }^{(5,25,26)}$. In our study, no relationship between nodule margins and malignancy was found ( $p>0.05)$.

One study showed that most malignant nodules have irregular borders and are hypoechogenic in appearance (21). Moon et al. (27) reported that irregular borders were not associated with malignancy, but hypoechogenicity was found in the vast majority of malignant nodules; this study is consistent with the results of our study. In addition, many studies have found that nodule sizes $10 \mathrm{~mm}$ or greater are not necessarily benign ${ }^{(28)}$, and one study recommended FNAB evaluation of nodules larger than $5 \mathrm{~mm}^{(27)}$.

USG findings have been shown to complement FNAB for nodules with unknown follicular lesions or atypia. In this study, it was stated that when hypoechogenicity is longer than a nodule's width, USG can be very helpful for diagnosing malignancy ${ }^{229}$. Furthermore, if it is possible to perform nodule elastography during Doppler USG evaluation, the diagnosis accuracy of preoperative malignancy can be very high without requiring FNAB evaluation (30).

Table 2. Statistical evaluation.

\begin{tabular}{|c|c|c|c|c|c|c|c|}
\hline & \multicolumn{3}{|c|}{ Doppler USG } & & \multicolumn{3}{|l|}{ TIRADS } \\
\hline & $\begin{array}{l}\text { Benign } \\
(\mathrm{n} / \%)\end{array}$ & $\begin{array}{l}\text { Malignant } \\
(\mathrm{n} / \%)\end{array}$ & $\begin{array}{l}\text { Total } \\
\text { (n/\%) }\end{array}$ & & $\begin{array}{l}\text { Benign } \\
(\mathrm{n} / \%)\end{array}$ & $\begin{array}{l}\text { Malignant } \\
(\mathrm{n} / \%)\end{array}$ & Total (n/\%) \\
\hline Peripheral vascularity & $17(13.9)$ & $14(11.5)$ & $31(25.4)$ & TIRADS 4 & $44(36.1)$ & $10(8.2)$ & $54(44.3)$ \\
\hline Internal vascularity & $33(27.0)$ & 19 (15.6) & $52(42.6)$ & TIRADS 5 & $7(5.7)$ & $23(18.9)$ & $30(24.6)$ \\
\hline
\end{tabular}



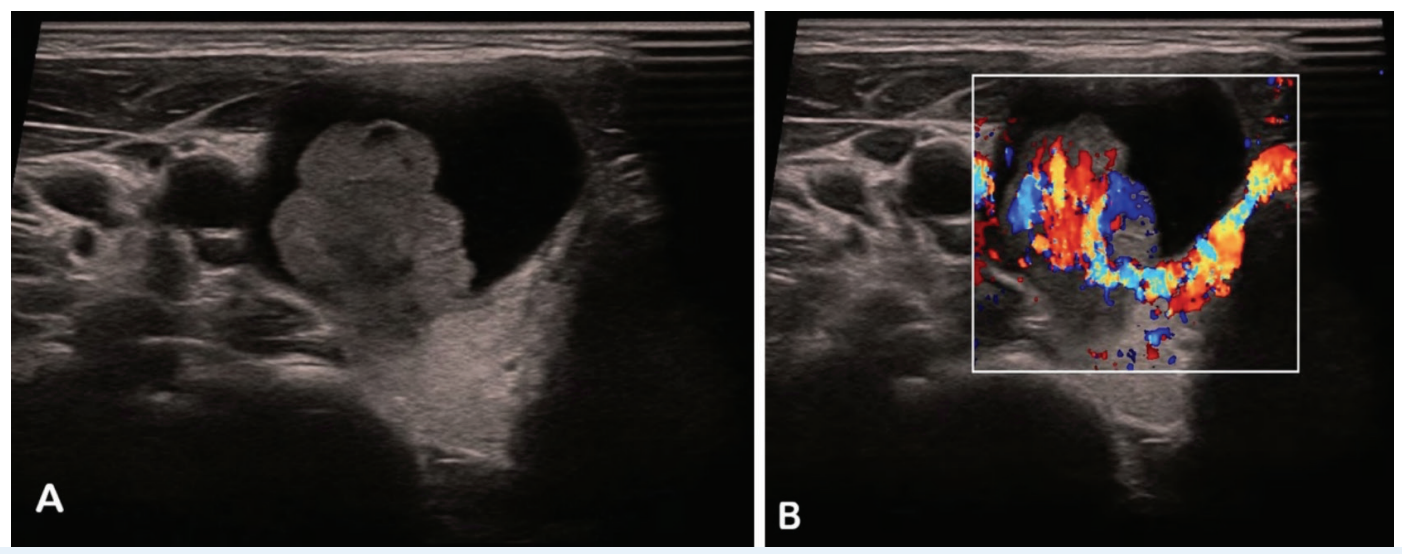

Figure 1. 27-year-old female patient. A) By grayscale ultrasound, there is a solid-cystic nodule with a regular margin in the right lobe. B) Doppler USG shows intense intranodular vascularity

USG: Ultrasonography

\section{Table 3. Doppler ultrasonography and TIRADS findings}

\begin{tabular}{|l|l|}
\hline Sonographic feature & Statistical results $(\mathbf{p})$ \\
\hline Hypoechogenity & $<0.05(0.028)$ \\
\hline Vascularity & $<0.05(0.016)$ \\
\hline Hypoechoic halo & $<0.05(0.0014) r=-0.285$ \\
\hline Microcalcifications & $<0.05(0.0229)$ \\
\hline Nodule margin (irregular border) & $>0.05(0.322)$ \\
\hline Component (solid-complex) & $>0.05(0.724)$ \\
\hline USG: Ultrasonography, TIRADS: Thyroid Imaging Reporting and Data System \\
\hline
\end{tabular}

\section{Study Limitations}

Our study found that the increase in vascularity and hypoechogenicity and the presence of microcalcification were directly proportional to malignancy risk. Further, we observed that the risk of malignancy decreases with the presence of a hypoechoic halo. However, no significant relationship was found between nodule margins and their component and malignancy risk. The limitation of our study is that it does not include a wide range of nodule sizes. This is because we compared Doppler USG and histopathology results in patients who had decided to operate.

\section{CONCLUSION}

Taken together with previous research, our results indicate that Doppler USG examination is essential in the evaluation of thyroid nodules and that the accuracy of preoperative diagnosis can be increased to $95 \%$ or more by combining Doppler USG with FNAB.
Ethics Committee Approval: Approval was obtained from the University of Health Sciences Turkey Haseki Training and Research Hospital Non-Drug Clinical Research Ethics Committee.

Informed Consent: In addition, informed consent was obtained from all patients.

Conflict of Interest: No conflict of interest was declared by the authors.

Financial Disclosure: The authors declared that this study received no financial support.

Etik Kurul Onayı: Onay, Sağlık Bilimleri Üniversitesi Haseki Eğitim ve Araștırma Hastanesi İlaç Dışı Klinik Araștırmalar Etik Kurulu'ndan alındı.

Hasta Onayı: Tüm hastalardan bilgilendirilmiş onam alındı.

Çıkar Çatıșması: Yazarlar tarafından çıkar çatışması bildirilmemiştir.

Finansal Destek: Yazarlar tarafindan finansal destek almadıkları bildirilmiştir.

\section{REFERENCES}

1. Harach HR, Franssila KO, Wasenius VM. Occult papillary carcinoma of the thyroid. A "normal" finding in Finland. A systematic autopsy study. Cancer. 1985;5:531-8. doi: 10.1002/1097-0142(19850801)56:3<531::aidcncr2820560321>3.0.co;2-3.

2. Singer PA, Cooper DS, Daniels GH, Ladenson PW, Greenspan FS, Levy EG, et al. Treatment guidelines for patients with thyroid nodules and well-differentiated thyroid cancer. American Thyroid Association. Arch ;156:2165-72.

3. Lyshchik A, Moses R, Barnes SL, Higashi T, Asato R, Miga MI, et al. Quantitative analysis of tumor vascularity in benign and malignant 
solid thyroid nodules. J Ultrasound Med. 2007;26:837-46. doi: 10.7863/ jum.2007.26.6.837.

4. Tan GH, Gharib H. Thyroid incidentalomas: management approaches to nonpalpable nodules discovered incidentally on thyroid imaging. Ann Intern Med 1997;126:226-31. doi: 10.7326/0003-4819-126-3-19970201000009.

5. Popowicz B, Klencki M, Lewinski A, Slowinska-Klencka D. The usefulness of sonographic features in selection of thyroid nodules for biopsy in relation to the nodule's size. Eur J Endocrinol. 2009;161:103-11. doi: 10.1530/EJE-09-0022. Epub 2009 Apr 17.

6. Baier ND, Hahn PF, Gervais DA, Samir A, Halpern EF, Mueller PR, et al. Fine-needle aspiration biopsy of thyroid nodules: experience in a cohort of 944 patients. AJR Am J Roentgenol. 2009;193:1175-9. doi: 10.2214/ AJR.08.1840.

7. Frates MC, Benson CB, Charboneau JW, Cibas ES, Clark OH, Coleman $B G$, et al. Management of thyroid nodules detected at US: Society of Radiologists in Ultrasound consensus conference statement. Radiology. 2005;237:794-800. doi: 10.1148/radiol.2373050220.

8. Marqusee E, Benson CB, Frates MC, Doubilet PM, Larsen PR, Cibas ES, et al. Usefulness of ultrasonography in the management of nodular thyroid disease. Ann Intern Med. 2000;133:696-700. doi: 10.7326/00034819-133-9-200011070-00011.

9. Gharib H, Goellner JR. Fine-needle aspiration biopsy of the thyroid: an appraisal. Ann Intern Med 1993;118:282-9. doi: 10.7326/0003-4819-1184-199302150-00007.

10. Hamberger B, Gharib H, Melton LJ 3rd, Goellner JR, Zinsmeister AR. Fine-needle aspiration biopsy of thyroid nodules. Impact on thyroid practice and cost of care. Am J Med 1982;73:381-4.

11. Mittendorf EA, Tamarkin SW, McHenry CR. The results of ultrasoundguided fine-needle aspiration biopsy for evaluation of nodular thyroid disease. Surgery 2002;132:648-3. doi: 10.1067/msy.2002.127549.

12. Gulcelik NE, Gulcelik MA, Kuru B. Risk of malignancy in patients with follicular neoplasm: predictive value of clinical and ultrasonographic features. Arch Otolaryngol Head Neck Surg. 2008;134:1312-5. doi: 10.1001/archotol.134.12.1312.

13. Cooper DS, Doherty GM, Haugen BR, Kloos RT, Lee SL, Mandel SJ, et al. Management guidelines for patients with thyroid nodules and differentiated thyroid cancer. Thyroid. 2006;16:109-42. doi: 10.1089/ thy.2006.16.109.

14. Iannuccilli JD, Cronan JJ, Monchik JM. Risk for malignancy of thyroid nodules as assessed by sonographic criteria: the need for biopsy. J Ultrasound Med.2004;23:1455-64. doi: 10.7863/jum.2004.23.11.1455.

15. Frates MC, Benson CB, Charboneau JW, et al. Society of Radiologists in Ultrasound. Management of thyroid nodules detected at US: Society of Radiologists in Ultrasound consensus conference statement. Radiology. 2005;237:794-800. doi: 10.1148/radiol.2373050220.

16. American Thyroid Association (ATA) Guidelines Taskforce on Thyroid Nodules and Differentiated Thyroid Cancer. Cooper DS, et al. Revised American Thyroid Association management guidelines for patients with thyroid nodules and differentiated thyroid cancer. Thyroid 2009;19:1167214. doi: 10.1089/thy.2009.0110.

17. Gharib H, Papini E, Valcavi R, et al. AACE/AME Task Force on Thyroid Nodules. American Association of Clinical Endocrinologists and Associazione Medici Endocrinologi medical guidelines for clinical practice for the diagnosis and management of thyroid nodules. Endocr Pract. 2006;12:63-102.

18. Cappelli C, Castellano M, Pirola I, et al. Thyroid nodule shape suggests malignancy. Eur J Endocrinol. 2006;155:27-31. doi: 10.1530/eje.1.02177.

19. Lin JD, Chao TC, Huang BY, et al. Thyroid cancer in the thyroid nodules evaluated by ultrasonography and fine-needle aspiration cytology. Thyroid. 2005;15:708-17.

20. Lee YH, Kim DW, In HS, Park JS, Kim SH, Eom JW, et al. Differentiation between benign and malignant solid thyroid nodules using an US classification system. Korean J Radiol. 2011;12:559-67.

21. Kovacevic DO, Skurla MS. Sonographic diagnosis of thyroid nodules: correlation with the results of sonographically guided fine-needle aspiration biopsy. J Clin Ultrasound. 2007;35:63-7.

22. Kim EK, Park CS, Chung WY, Oh KK, Kim DI, Lee JT, et al. New sonographic criteria for recommending fine-needle aspiration biopsy of nonpalpable solid nodules of the thyroid. AJR Am J Roentgenol. 2002;178:687-91.

23. Ugurlu S, Caglar E, Yesim TE, Tanrikulu E, Can G, Kadioglu P. Evaluation of thyroid nodules in Turkish population. Intern Med. 2008;47:205-9.

24. Taneri F, Kurukahvecioglu O, Ege B, Yilmaz U, Tekin E, Cifter C, et al. Prospective analysis of 518 cases with thyroidectomy in Turkey. Endocr Regul. 2005;39:85-90.

25. Koike E, Noguchi S, Yamashita H, Murakami T, Ohshima A, Kawamoto $\mathrm{H}$. Ultrasonographic characteristics of thyroid nodules: prediction of malignancy. Arch Surg.2001;136:334-7.

26. Algin O, Algin E, Gokalp G, Ocakoglu G, Erdogan C, Saraydaroglu O, et al. Role of duplex power Doppler ultrasound in differentiation between malignant and benign thyroid nodules. Korean J Radiol. 2010;11:594602.

27. Moon WJ, Jung SL, Lee JH, Na DG, Baek JH, Lee $Y H$, et al. Benign and malignant thyroid nodules: US differentiation--multicenter retrospective study. Radiology. 2008;247:762-70.

28. Papini E, Guglielmi R, Bianchini A, Crescenzi A, Taccogna S, Nardi F, et al. Risk of malignancy in nonpalpable thyroid nodules: predictive value of ultrasound and color-Doppler features. J Clin Endocrinol Metab. 2002;87:1941-6.

29. Yoo WS, Choi HS, Cho SW, Moon JH, Kim KW, Park HJ, et al. The role of ultrasound findings in the management of thyroid nodules with atypia or follicular lesions of undetermined significance. Clin Endocrinol (Oxf). 2014;80:735-42. doi: 10.1111/cen.12348. Epub 2013 Oct 30.

30. Kızılkaya MC, Erözgen F, Akıncı M, Kaplan R, Tüzün S, Çıtlak G. The predictive value of elastography in thyroid nodules and its comparison with fine-needle aspiration biopsy results. Ulus Cerrahi Derg. 2014;30:147-52. doi: 10.5152/UCD.2014.2519. eCollection 2014. 